\title{
Localization of Insulin in Mouse Tissues Using Fluorescence Microscopy and Light Microscope and High Resolution Autoradiography.
}

\author{
V. Maggi, L. M. Franks, P.D. Wirson and A. W. Carbonelu \\ Tissue and Organ Culture Unit, Imperial Cancer Research Fund, Lincoln's Inn Fields, London, W.C. 2
}

Received: April 25, 1968

\begin{abstract}
Summary. Starved and fed mice were injected intravenously with either fluorescent or ${ }^{125}$ I-insulin and the localization of the hormone was investigated in various tissues. The fluorescent hormone was found in the kidney of starved animals only, whereas the radioactive hormone was found in the proximal convoluted tubule cells of the kidney of both fed and fasted animals, although the latter group appeared to contain more radioactivity than the first. With high resolution techniques the radioactivity in the kidney was found in the brush border, the apical vacuoles, the apical mitochondria and the nucleus, and never in the Golgi apparatus or the lysosomes. All other tissues contained radioactivity due to the hormone, but no difference in either the amount or the localization was found between fed an starved animals. It is concluded that the process of absorption of insulin by the cells of the proximal convoluted tubules is specific and that the hormone is not degraded in a way similar to other proteins, but is likely to be stored and to control cellular metabolic processes from its sites of localization.
\end{abstract}

Localisation de l'insuline dans les tissus de souris en utilisant la microscopie à fuorescence, le microscope optique et l'autohistoradiographie à haute résolution

Résumé. La localisation d'insuline marquée avec $\mathrm{I}^{\mathbf{1 2 5}}$ ou avec de l'isothiocyanate de fluorescéine a été étudiée au moyen d'autohistoradiographie au microscope optique, au microscope électronique et au moyen de microscopie àfluorescence dans les tissus de souris à jeun et de souris alimentées normalement. L'hormone fluorescente a été trouvée dans les cellules des tubules proximaux du rein de souris à jeun seulement, tandis que l'hormone radioactive a été repérée aussi dans le rein de souris alimentées, bien qu'en quantité inférieure à celle trouvée chez les souris à jeun. Au microscope électronique la radioactivité est présente dans le rein dans la bordure en brosse, les vacuoles et les mitochondries apicales et le noyau, mais pas dans l'appareil de Golgi ou dans les lysosomes. -
L'hormone radioactive est aussi présente dans les autres tissus mais sans différence quantitative entre les souris à jeun et les souris alimentées. Les auteurs concluent que le procédé de ré-absorption de l'insuline par les cellules des tubules proximaux du rein est spécifique: I'hormone n'est pas dégradée de la même façon que les autres protéines mais probablement stockée afin de contrôler les processus métaboliques relevant des organelles subcellulaires dans lesquelles elle se trouve.

Lokalisierung von Insulin in Mäusegeweben durch Fluoreszenzmikroskopie sowie Licht- und Autoradiographie mit hohem Auflösungsvermögen

Zusammenfassung. Gefütterte und fastende Mäuse erhielten fluioreszierendes oder mit ${ }^{125} \mathrm{~J}$ markiertes Insulin i.v. Die Lokalisation des Insulins in den Geweben wurde untersucht. Nur bei Tieren im Hungerzustand fand sich das fluoreszierende Hormon in den Nieren, während sich das radioaktive Insulin bei gefütterten und fastenden Tieren in den proximalen Tubulusschlingen der Nieren nachweisen ließ. Diefastenden Tiere schienen dabei mehr Radioaktivität aufzuweisen. Wurden die Nieren unter Verwendung von Techniken mit hohem Auflösungsvermögen untersucht, so fand sich die Radioaktivität im Bürstensaum, in den apikalen Vakuolen und Mitochondrien und dem Kern, jedoch nicht im Golgi-Apparat oder den Lysosomen. Alle anderen Gewebe enthielten Hormon-Radioalktivität, aber weder ihre Menge noch ihre Lokalisation unterschieden sich bei gefütterten und fastenden Tieren. Es wird gefolgert, daß der Proze $\beta$ der Insulinabsorption durch die Zellen der proximalen Tubulusschlingen spezifisch ist und daß das Hormon nicht in ähnlicher Weise wie andere Eiweißkörper abgebaut wird. Wahrscheinlich kommt es über eine Speicherung zu einer Steuerung der entsprechenden Stoffwechselprozesse in den subzellulären Organellen, in denen das Hormon sich befindet.

Key-words: Insulin, mouse tissues, kidney fluorescence microscopy, microscopy, autoradiography.

\section{Introduktion}

The localization of injected insulin in animal tissues has been reported by STEIN and Gross (1959) and by WORTHINGTON, JoNeS and BUSE (1964) using autoradiography of ${ }^{131} \mathrm{I}$ and ${ }^{125} \mathrm{I}$-labelled insulin at light microscope level, and by MAGGI (1966) using fluorescent insulin. In all cases the hormone was found to be present predominantly in the kidney, the elastic tissue and the striated muscles of rats and mice; moreover, preliminary fasting was found necessary in the case of mice for the kidney proximal convoluted tubules of these animals to absorb the hormone (MaGGI, 1966). In the course of the experiments with fluorescent insulin, the mechanism of absorption of the hor- mone by the kidney cells was not elucidated. The lcoalization of the fluorescent hormone in areas of the cells where protein absorption routinely takes place by pinocytosis (brush border) and where lysosomes were present, suggested that pinocytosis was the mechanism involved, and that this could be followed by lysosomal digestion. This mechanism has been demonstrated to operate during the absorption of horseradish peroxidase (Straus, 1963; GraHay and KarNOVSKY (1966)), of ferritin (MAUNSBACH, 1966 b) and of 125I-albumin (MAUNSBACH, 1966a) by the cells of the rat kidney proximal convoluted tubules. Since the use of 125I-labelled proteins for the purpose of autoradiography has become well-established (KAYES, MAUNSBACH and UlLbERG, 1962; MAUNSBACH, 1966a), 
an attempt has been made to gain information on the absorption mechanism and on the sub-cellular localization of the hormone by means of this technique using ${ }^{125} \mathrm{I}$-insulin of high specific activity. The fluorescent lysosomal marker Trypan Blue (BECK, 1965) was also used in conjunction with fluorescent insulin to further elucidate this point, and a correlation between results obtained with autoradiography and with fluorescent microscopy has been attempted.

\section{Materials and Methods}

Crystalline ox insulins from Wellcome Research Laboratories, Beckenham, Kent; Novo Research Institute, Copenhagen; and Lilly Research Laboratories, Indianapolis, Ind., were labelled with fluorescein isothiocyanate (Nutritional Biochemical Corporation) as described by MAGGI (1966) with the following modifications: the dialysate was centrifuged and the precipitate was re-dissolved in $0.1 \mathrm{M}$ bicarbonate buffer at pH 9.1 and eluted through a G25 Sephadex column of $2 \times 16 \mathrm{~cm}$ with a bed volume of $30 \mathrm{ml}$, using $0.1 \mathrm{M}$ bicarbonate buffer as the eluant. Fractions of $3 \mathrm{ml}$ were collected and protein content was estimated in each fraction by the method of LowRY, RosEBRougH, FARR and RANDALL (1951). Fluorescence was detected visually with a Wood U.V. lamp. Non-fluorescent (native) and fluorescent insulins were further tested by electrophoresis on cellulose acetate strips in $0.025 \mathrm{MI}$ barbitone buffer at $\mathrm{pH} 8.6$ with $0.3 \mathrm{~mA} / \mathrm{cm}$ strip width. Fluorescence was viewed with a Wood U.V. lamp and proteins were stained with $0.002 \%$ Nigrosin in $2 \%$ acetic acid. All other tests were as described by MaGGI (1966).

Trypan blue: this dye was used as a $0.5 \%$ solution in $0.9 \% \mathrm{NaCl}$, to assess the possible involvement of lysosomes in the uptake of insulin ( $\mathrm{BECK}, 1965)$.

${ }^{125}$ I-labolling: this was performed according to Grennwood, Hunter and Glover (1963). Specific activity of the protein and level of contamination by degradation products were assayed according to these authors.

\section{Experimental Procedure}

A total of 80 male Simpson mice $6-9$ months old was used. Half of these were starved for $18 \mathrm{~h}$ before receiving the protein to be investigated, and the other half were fed. Water was available ad libitum. The animals were killed by dislocation of the neck and the tissues required were excised rapidly and processed as described below.

1. FITC-insulin and Trypan blue: $1 \mathrm{ml}$ Trypan blue/30 g body weight was administered subcutaneously and the animals left to recover for two days, after which half of them were starved for 18 hours and the other half were fed before receiving $0.5 \mathrm{mg}$ of fluorescent insulin into the tail veins. Controls were animals both fed and starved but which did not receive FITC-insulin.

Tissues examined: heart, lung, liver, kidney, pan- creas, intestine, testis, prostatic complex, seminal vesicles, thigh muscle and peri-renal adipose tissue were frozen-dried in a Pearse-Edwards freeze-drying apparatus, fixed in paraformaldehyde vapour and embedded in paraffin; sections were cut at a thickness of $4 \mu$. Alternatively, the tissues were frozen in Arcton 12 and sectioned in a cryostat at a thickness of $8 \mu$. The sections were mounted directly into buffered glycerol at $\mathrm{pH} 7.4$ and observed with a Zeiss GFL fluorescence microscope equipped with an HBO 200 mercury lamp. Barrier and exciter filters used were $53 / 44$ and BG 12 and $50 / 44$ and BG 3 respectively.

2. Radioactive insulin: ${ }^{125} \mathrm{I}$-insulin was dissolved in $0.1 \mathrm{ml}$ phosphate buffer containing albumin and used immediately. Amounts varying between $0.2 \mu \mathrm{C} / \mathrm{g}$ and $0.6 \mu \mathrm{C} / \mathrm{g}$ body weight were injected intravenously and the animals killed after 5, 10 and 15 minutes.

Tissues examined: heart, lung, thigh muscle, liver, kidney, pancreas, intestine, testis, prostatic complex, seminal vesicles and peri-renal adipose tissue were taken for examination by light microscope autoradiography. They were fixed in formolcalcium for $24 \mathrm{~h}$, dehydrated in alcohol and paraffin-embedded. Sections were exposed for 2 days to 2 months with either Kodak AR 10 stripping film or L4 Ilford emulsion. Autoradiographs were processed according to PeLc (1947) or to Messier and LeBLond (1957), and post-stained with haematoxylin and eosin. Background was evaluated in areas outside the tissue and found to be negligible. For electron microscope autoradiography, liver, kidney and voluntary muscle were chopped in small blocks and fixed either in cold $2 \%$ glutaraldehyde or in cold $2 \% \mathrm{OsO}_{4}$ buffered with $0.1 \mathrm{M}$ cacodylate at $\mathrm{pH} 7.4$. The tissues were dehydrated and embedded routinely in Araldite according to GLAUERT (1965) and processed for autoradiography according to BUDD and PELC (1964). Exposure times varied between 3 and 7 weeks.

The autoradiographs were developed in Microdol for 3 minutes, stained with lead citrate and uranyl acetate, and observed with a Philips EM 75 or with an AEI EM6B electron microscope. The evaluation of the resolution of the technique, and hence of the subcellular localization of the radioactive source, obeyed the criteria layed down by CARo (1962) and by MAUNSBACH (1966a). According to these authors, the chances that silver grains may occur outside a labelled structure decrease with the increase in distance of the grains from the structure. Thus, when the developed silver grains were found packed exclusively above a subcellular structure the latter was assumed to contain radioactivity. When single grains could be resolved, the source of radioactivity was assumed to be within the smallest possible circle enclosing the grain (MACNsBACH, 1966a).

\section{Results}

FITC-insulins: Native crystalline insulins from all sources tested were found to separate electrophoretically as two bands which were stained by Nigrosin 
(Fig. 1). When the various insulins were coupled with FITC and eluted on a G25 Sephadex column, they separated as one band between tube 30 and 32 which contained both protein and fluorescence. The electrophoresis of such material revealed one fluorescent band migrating towards the anode (Fig. 2) and which stained with Nigrosin (Fig. 3).

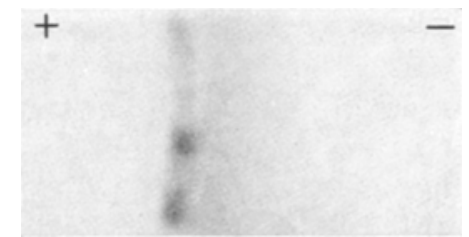

Fig. 1. Crystalline beef insulin (Novo) $10 \mu \mathrm{g}$ dissolved in $0.1 \mathrm{ml} 0.1 \mathrm{M}$ bicarbonate buffer, subjected to electrophoresis on cellulose acetate for 60 minutes and stained with $0.001 \%$ nigrosin in $2 \%$ acetic acid. A faintly positive band was present below the main insulin band

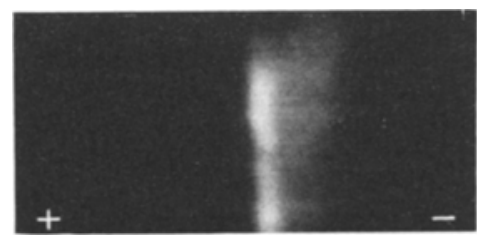

Fig. 2. Same insulin as above, but after coupling with FITC. Photographed in UV light. One band only is evident

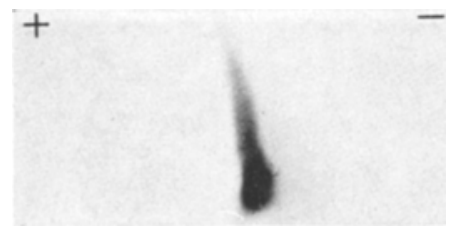

Fig. 3. Same as Fig. 2, but strip stained with Nigrosin. One band only is present, and corresponds to the fluorescent one. It shows a decrease in positive charge with respect to that shown in Fig. 1

The coupling with FITCappeared to have decreased the negative charge of the insulin molecule so that, under the conditions of separation described in this paper, the two bands present in the native preparations had fused to form one band only (compare Figs. 1 and 3). By varying the conditions of electrophoretic separation, however, it was possible to separate the FITC-insulin in two bands, the less positively charged of which was not fluorescent (MAGGr, unpublished). A fuller account of the results of the chemical analysis of insulins from various sources and of their behaviour when coupled with FITC and other fluorescent dyes will be published elsewhere (MAGGI, in preparation).

Radioactive insulins: the specific activity of ${ }^{125} \mathrm{I}$-insulins ranged between 90 and $179 \mu \mathrm{C} / \mu \mathrm{g}$, and the level of contamination by degradation products was never higher than $5 \%$.

The localization of FITC-insulin in the tissues of starved mice has been described elsewhere (MAGGI, 1966) and will not be reported here.
When FITC insulin was given to animals which had been pre-treated with Trypan blue and fully fed during the whole course of the experiment only the red fluorescence due to Trypan blue was found in the kidney proximal convoluted tubules. However, when the animals were fasted after the injection of Trypan blue, and before the injection of FTTC-insulin, green fluorescent granules were found in the cells of the epithelium of the Bowman's capsule and the proximal convoluted tubules. These granules sometimes appeared to be present at the same sites as the red Trypan blue granules, but usually it was possible to distinguish them above the Trypan blue granules (Fig. 4), on the brush border.

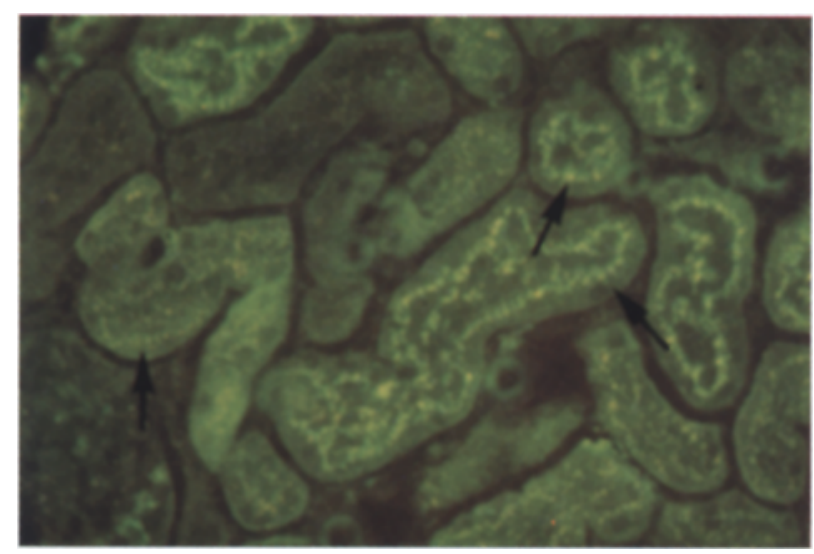

Fig. 4. Kidney of mouse injected with $1 \mathrm{ml} 0.1 \%$ Trypan blue, starved for $18 \mathrm{~h}$, injected with FITC-insulin and killed after 5 min. Exciter filter was BG 12 and barrier filters 53-44. Under these conditions FTTC-insulin appears as large yellow granules and Trypan blue-containing lysosomes appear red. Arrow points at site where red granules are distinctly below yellow granules with respect to lumen of the proximal convoluted tubule. In other areas, the two types of granules are superimposed. $\times 200$

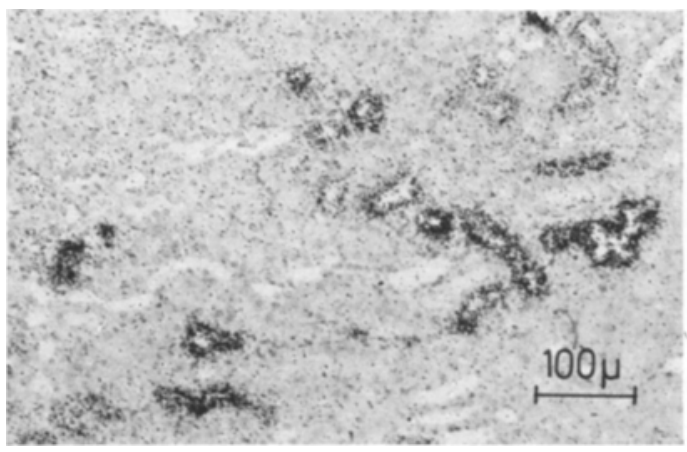

Fig. 5. Kidney of fully fed mouse injected $0.6 \mu \mathrm{C}{ }^{125} \mathrm{I}-$ insulin/g body weight. Autoradiograph 5 days exposure. $\times 100$

Light microscope autoradiography: most of the radioactive material was found in the kidney and was almost exclusively at the brush border in the proximal convoluted tubules and the Bowman's capsule (Figs.5-7). 


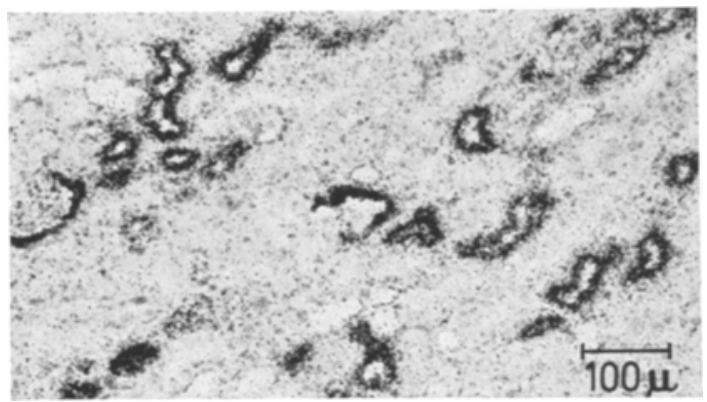

Fig. 6. Kidney of mouse starved for 18 hours and injected $0.6 \mu \mathrm{C}{ }^{125} \mathrm{I}$-insulin/g body weight. Autoradiograph 5 days exposure. There is more radioactivity per tubule, and more proximale convoluted tubules are labelled than in Fig. 5. $\times 100$ liver the radioactivity was mainly present in the hepatocytes around the portal spaces. In the pancreas it was found in the acinar tissue and/or in the basement membrane surrounding the islets of Langerhans, though not in the islet cells. In the spleen it was present on the capsule and the trabeculae, and not in the parenchyma. In the intestine some activity was found in the epithelium of the villi, but most was found where the submucosa forms the lamina propria of each villus (Fig. 8).

More radioactivity was found in the heart than in the voluntary muscle, but in both tissues it was lower than in the liver and considerably lower than in the kidney. The radioactive material was found along the sarcolemma of the fibres, in the small vessels and the

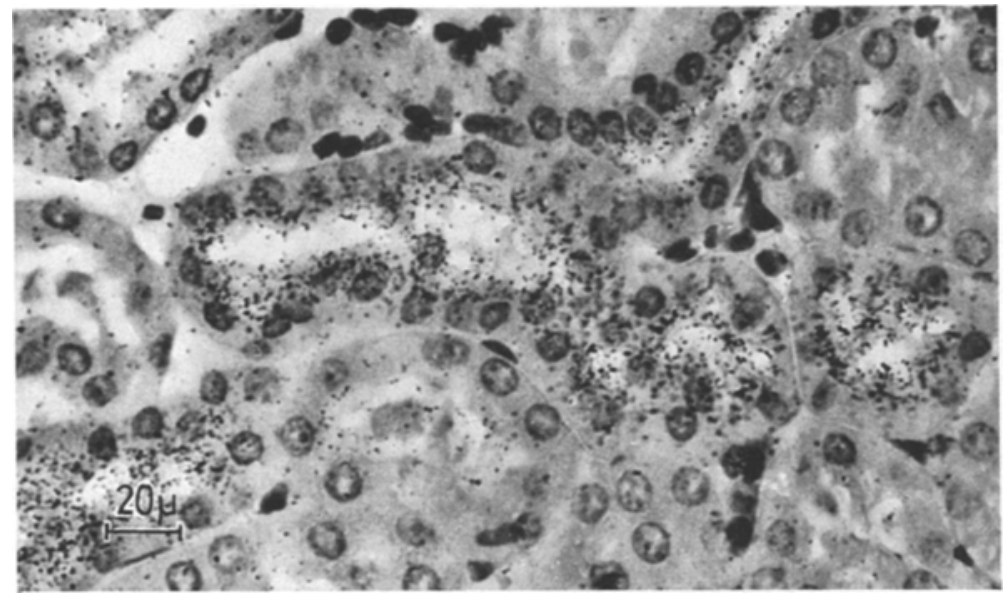

Fig. 7. Kidney of mouse injected with ${ }^{125} \mathrm{I}$ insulin. Experimental conditions as in Fig. 5 , but exposure for 1 day. Radioactivity is localized mainly in the supra-nuclear area of the cells of proximal convoluted tubule. $\times \mathbf{3 5 0}$

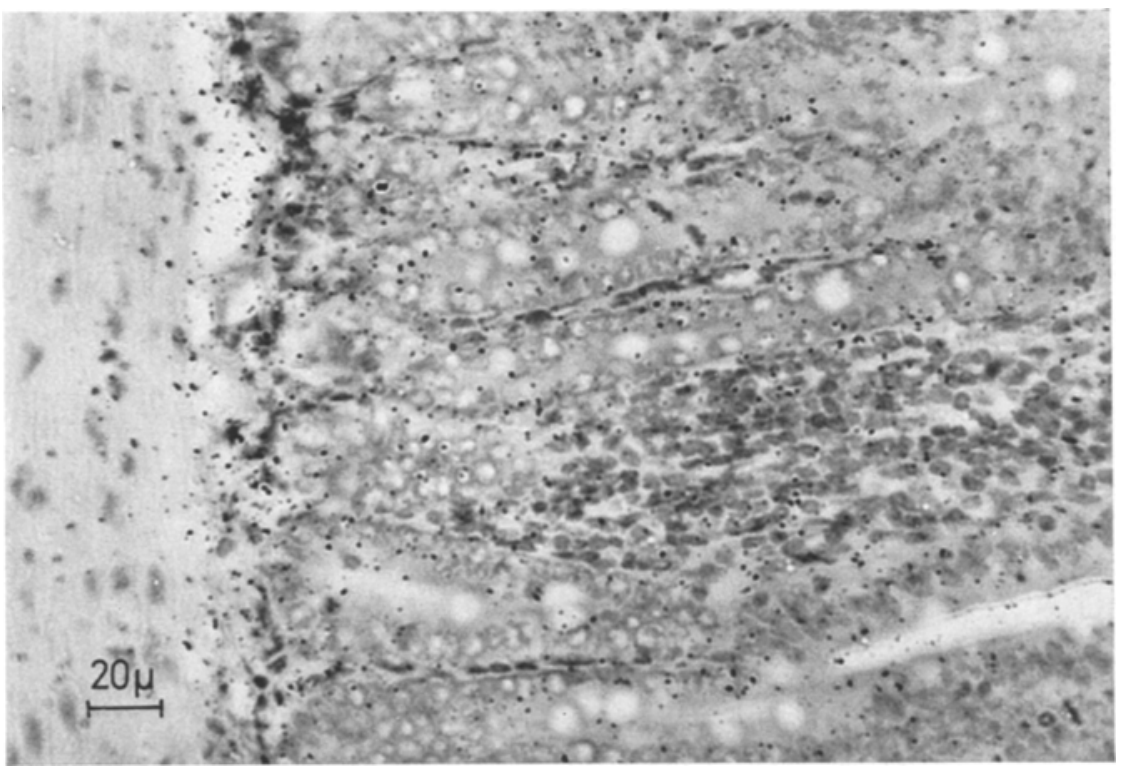

Fig. 8. Duodenum of same animal as in Fig. 6. Exposure 5 days. Radioactivity higher at junction between muscularis mucosa and villi, and decreasing from Brunner glands to apex of villi. $\times \mathbf{3 5 0}$

terial was found in all other tissues examined. In the The proximal convoluted tubules of starved animals (Fig. 6) appeared to have a higher grain density than those of fed animals (Fig. 5). Some radioactive ma- loose connective tissue present between the bundles of fibres, and also in the fibres themselves, without a clear-cut specific localization at this level (Figs. 9 and 10). 
The tunica albuginea and the interstitial cells of the testis were labelled consistently and some radioactive material was found occasionally in the germinal epithelium. In the ventral prostate the radioactivity was localized along the basement membrane, although

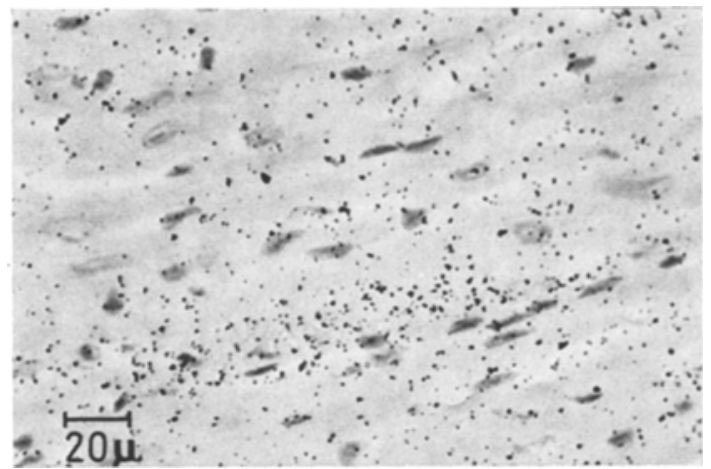

Fig. 9. Heart of same animal as in Fig. 6. Fxposure 5 days. Radioactivity mainly on sarcolemma; some also in fibres. $\times 350$

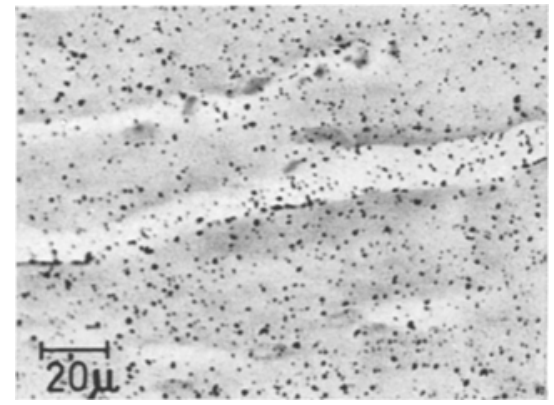

Fig. 10. Thigh muscle of fully-fed mouse injected with $0.6 \mu \mathrm{C}{ }^{125} \mathrm{I}$-insulin/g body weight. Section exposed to stripping film for 15 days. This tissue contained less radioactivity than heart. $\times 350$

in some cases it could be found also in the epithelium. In the seminal vesicles there was little or no radioactivity. In the lung there was little radioactivity, which appeared to be localised in some of the interalveolar cells. In all these tissues there was no difference in localization or amount of radioactivity whether the animals were fed or starved. The adipose tissue of the fed animals, however, appeared to contain considerably more radioactivity than that of the starved mice.

High resolution autoradiography: five to fifteen $\mathrm{min}$ utes after injection of ${ }^{125} \mathrm{I}$-insulin, silver grains were found on the microvilli, the large and the small apical vacuoles of the cells of the proximal convoluted tubules, in the apical mitochondria of the cells and across the cell membranes (Figs. 11-18). Some nuclei of the cells of the proximal convoluted tubules were labelled (Fig. 19). Silver grains were never found in the pinocytio vesicles, the lysosomes or the Golgi apparatus.

The morphological and ultrastructural changes which accompany starvation for $18 \mathrm{~h}$ in mouse kidney have been described elsewhere (MAGGI and ODDY,
1968). The main feature is the vacuolation of the cytoplasm and the fatty degeneration which takes place mainly at the base of the cells of the proximal convoluted tubule. No radioactivity was found in the cytoplasmic vacuoles and only oceasionally was it pos-

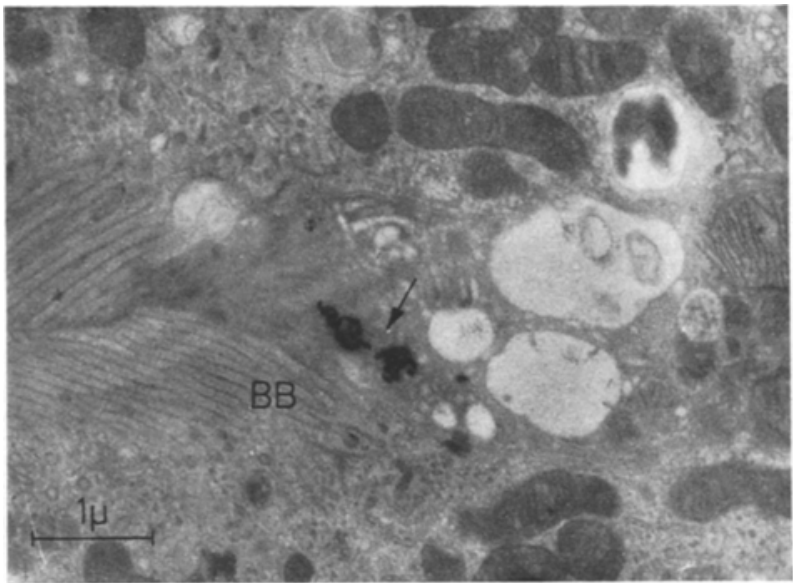

Fig. 11. Kidney of fully-fed animal injected with $0.15 \mu \mathrm{C}$ 125 I-insulin/g body weight and killed after $15 \mathrm{~min}$. Tissue fixed for $2 \mathrm{~h}$ in $2 \%$ glutaraldehyde in $0.1 \mathrm{M}$ cacodylate buffer at $\mathrm{pH}$ 7.4, dehydrated in ethanol, embedded in Araldite. Autoradiograph 6 weeks exposure. Section stained with uranyl acetate and lead citrate. Radioactivity (arrow) in brush border (BB) $\times 15000$

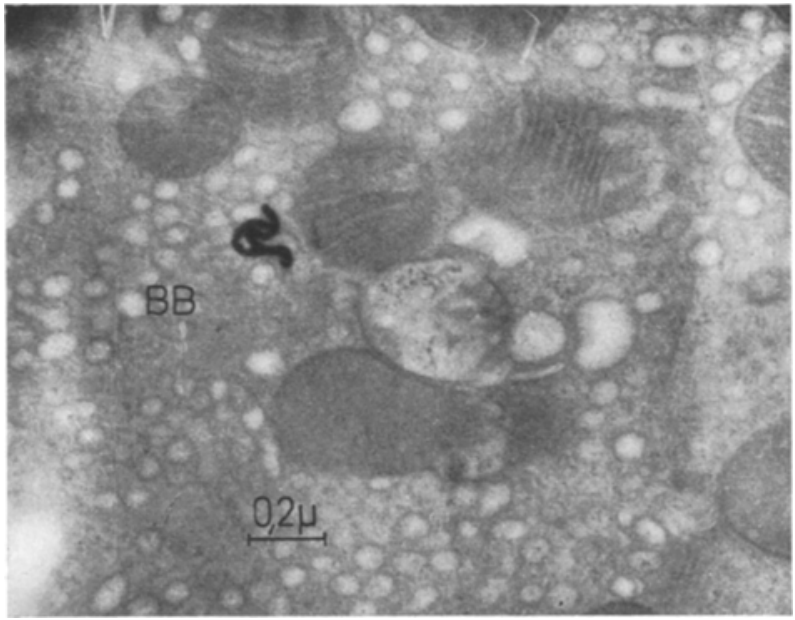

Fig. 12. Kidney of animal starved for $18 \mathrm{~h}$, injected with $0.15 \mu \mathrm{C}{ }^{125} \mathrm{I}$-insulin/g body weight and killed after $10 \mathrm{~min}$. Autoradiograph 3 weeks exposure. Radioaetivity in brush border which has been cut transversoly. $\times 50000$

sible to observe some silver grains in the fat droplets of the kidney. Apart from these occasional findings, there appeared to be no difference in the localization of radioactive material between fed and fasted animals.

In the liver of fed animals the radioactivity was loealised in the glycogen areas or in the mitochondria in proximity to the glycogen areas (Fig. 20). Occasionally, some nuclei appeared labelled. Radioactivity was never found in the lysosomes or the Golgi apparatus. 
The liver of the starved animals appeared deprived of glycogen and contained a very great number of periportal lipid droplets. In these animals the radioactivity was found in the mitochondria and close to the lipid droplets (Fig. 21) as well as in some nuclei of the hepatocytes.

In the voluntary muscle only a little radioactivity was found and this was localized in the mitochondria
Figs. 13-14. Kidney of animal starved for $18 \mathrm{~h}$, injected with $0.3 \mu \mathrm{C} \quad{ }^{125} \mathrm{~T}$-insulin $/ \mathrm{g}$ body weight and killed after $15 \mathrm{~min}$. Sections exposed for 3 weeks. Radioactivity is present on brush border (BB), apical vacuoles (AV) and apical mitochondria (AM) Fig.13 $\times 21000 ; \quad$ Fig. 14 $\times 9500$

Fig. 14

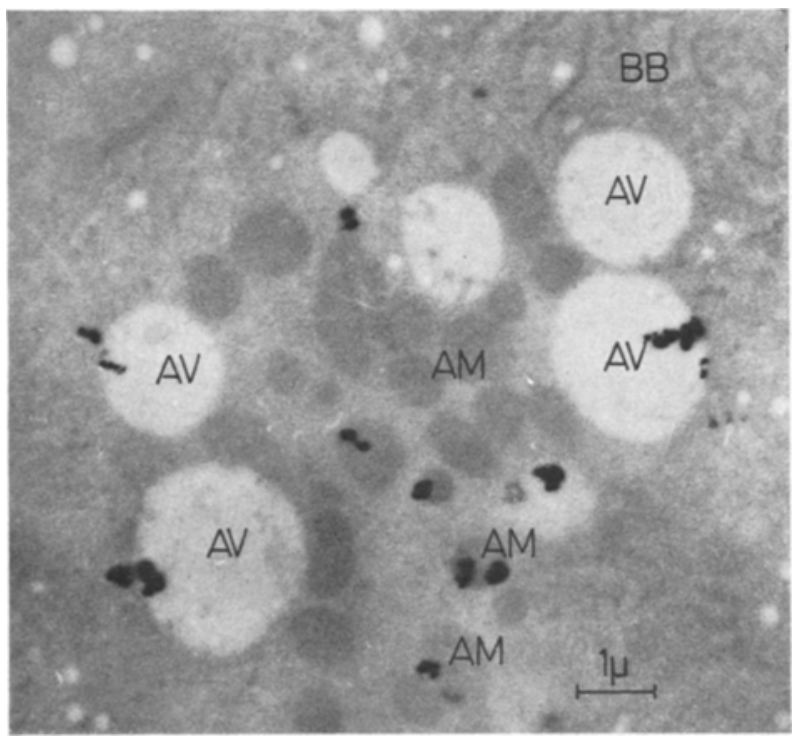

Fig. 13
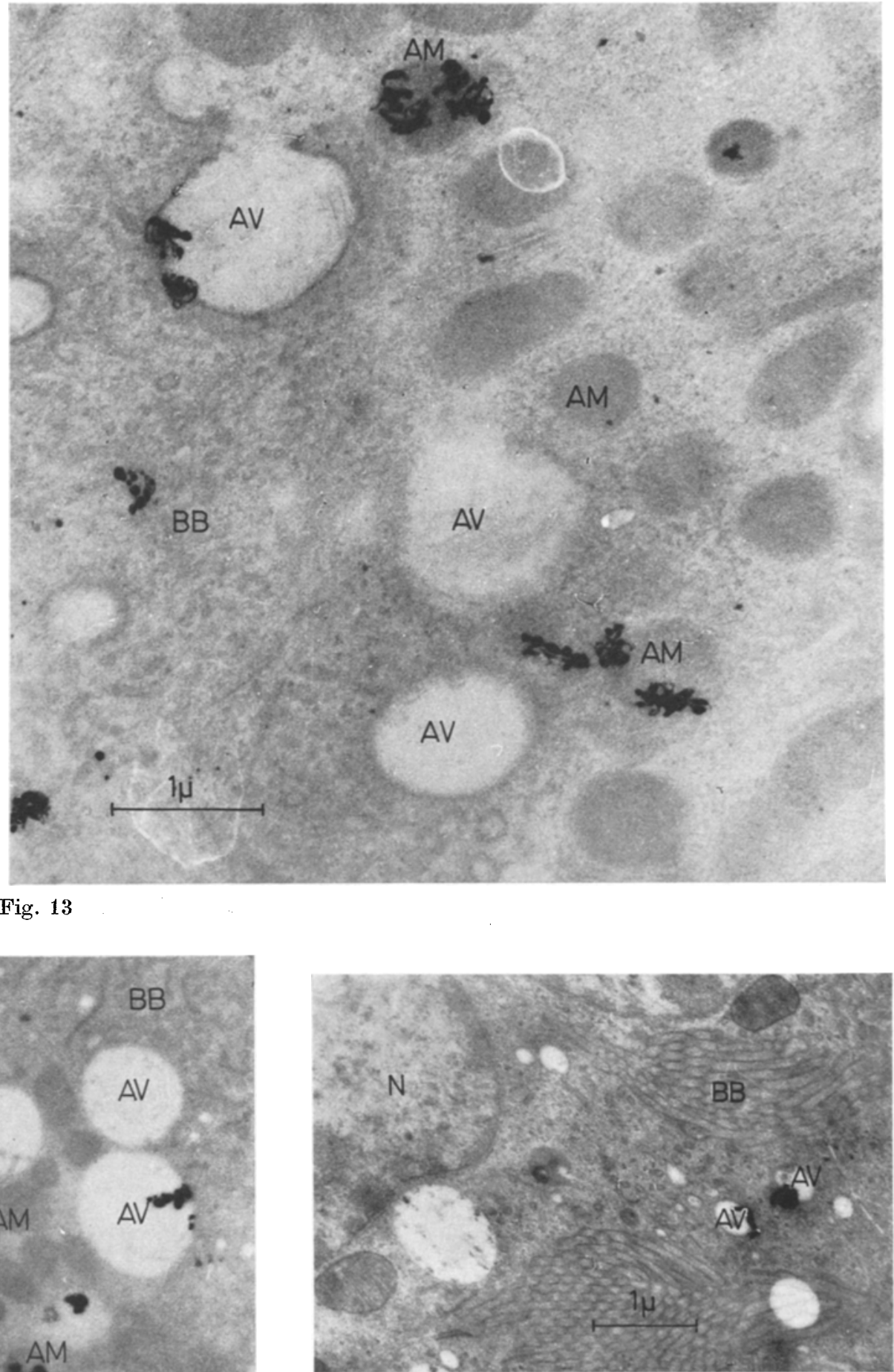

Fig. 15. Kidney of mouse starved for $18 \mathrm{~h}$, injected with $0.15 \mu \mathrm{C}{ }^{125} \mathrm{I}$-insulin/g body weight and killed after $15 \mathrm{~min}$. Experimental conditions as in Fig. 11 but section exposed for 3 weeks. Radioactivity in apical vacuoles (AV). 


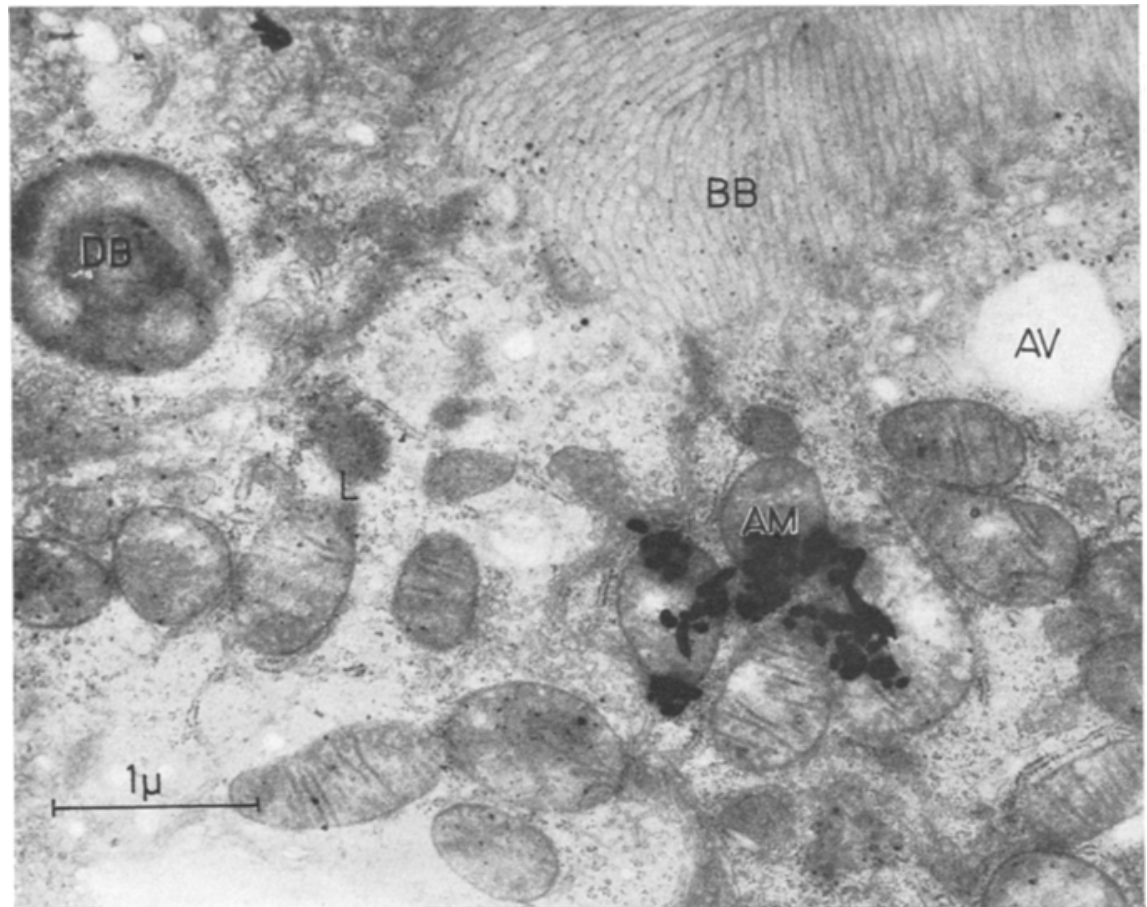

Fig. 16. Kidney of mouse starved for 18 hours, injected with $0.15 \mu \mathrm{C}{ }^{125} \mathrm{I}$-insulin/g body weight and killed after 5 min. Section exposed for 3 weeks. Radioactivity in apical mitochondria (AM). No radioactivity in residual dense bodies (DB). $\times 21000$

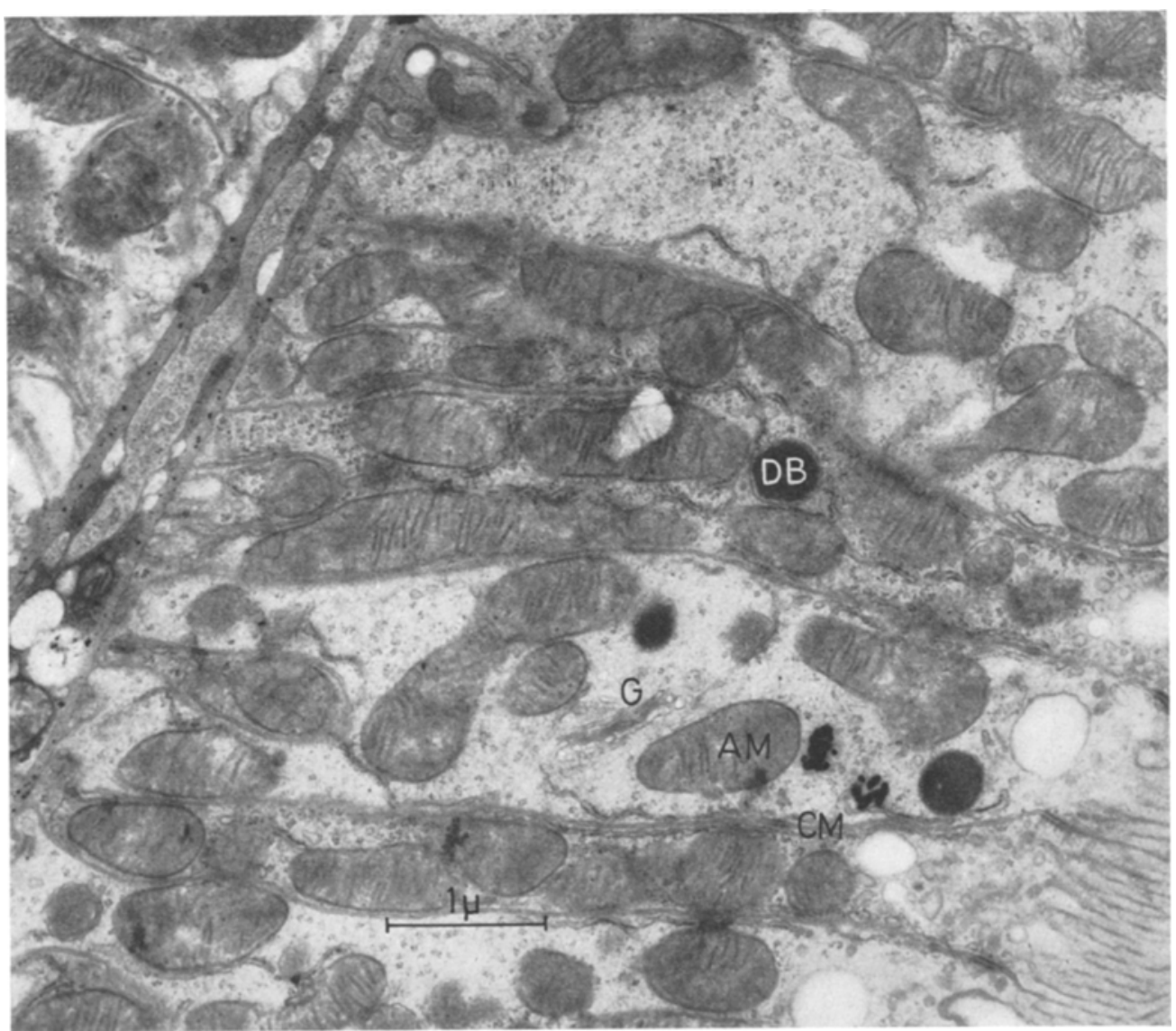

Fig. 17. Same animal as in Fig. 15. Radioactivity on cell membrane (CM) and in area close to apical mitochondrion (AM). No radioactivity in dense bodies (DB) or Golgi apparatus (G). $\times 18000$ 
and along the myofibrils in the connective tissue. Occasionally some silver grains could be seen in the myofibrils. No difference between starved and fed animals was observed (Figs. 22-24).

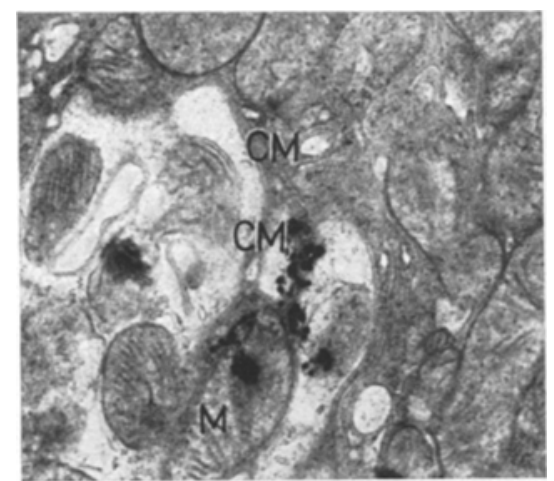

Fig. 18. Kidney of fully fed mouse injected $0.3 \mu \mathrm{C}{ }^{125} \mathrm{I}$ insulin/g body weight and killed after $5 \mathrm{~min}$. Section exposed for 6 woeks. Radioactivity is present across the cell membrane and in a mitochondrion (M) of a proximal convoluted tubule cell. $\times 18000$ in partial disagreement with the findings of TIETze, MorTtmore and Lomax (1962) and of BRomer, K NAPPShemerar, Berns and Arquilla (1967). These authors found that using a molecular ratio FITC: insulin of 1 for labelling the hormone, the resulting FITC-insulin was monosubstituted, had maintained its immunological reactivity but had lost $50 \%$ of its biological activity (as assayed by the mouse convulsion test), and contained some uncoupled insulin. When a higher molecular ratio of 2 was used, a di-substituted FITCinsulin appeared which was inactive both immunologically and biologically. It is possible that the use of an intermediate molecular ratio together with a longer period of coupling in our experiments might account for the discrepancies between our data and those of Tretze et al. (1962) and Bromer et al. (1967).

Immunological and chemical properties of ${ }^{125} \mathrm{I}$-insulin appear to be maintained under the conditions of iodination used (GREENWOod et al., 1963; SCHALCH, 1966; Izzo, Bale, Izzo and Roncone, 1964a; Izzo, Roncone, Izzo and BALE, 1964b) although the biological properties of the hormone may have been

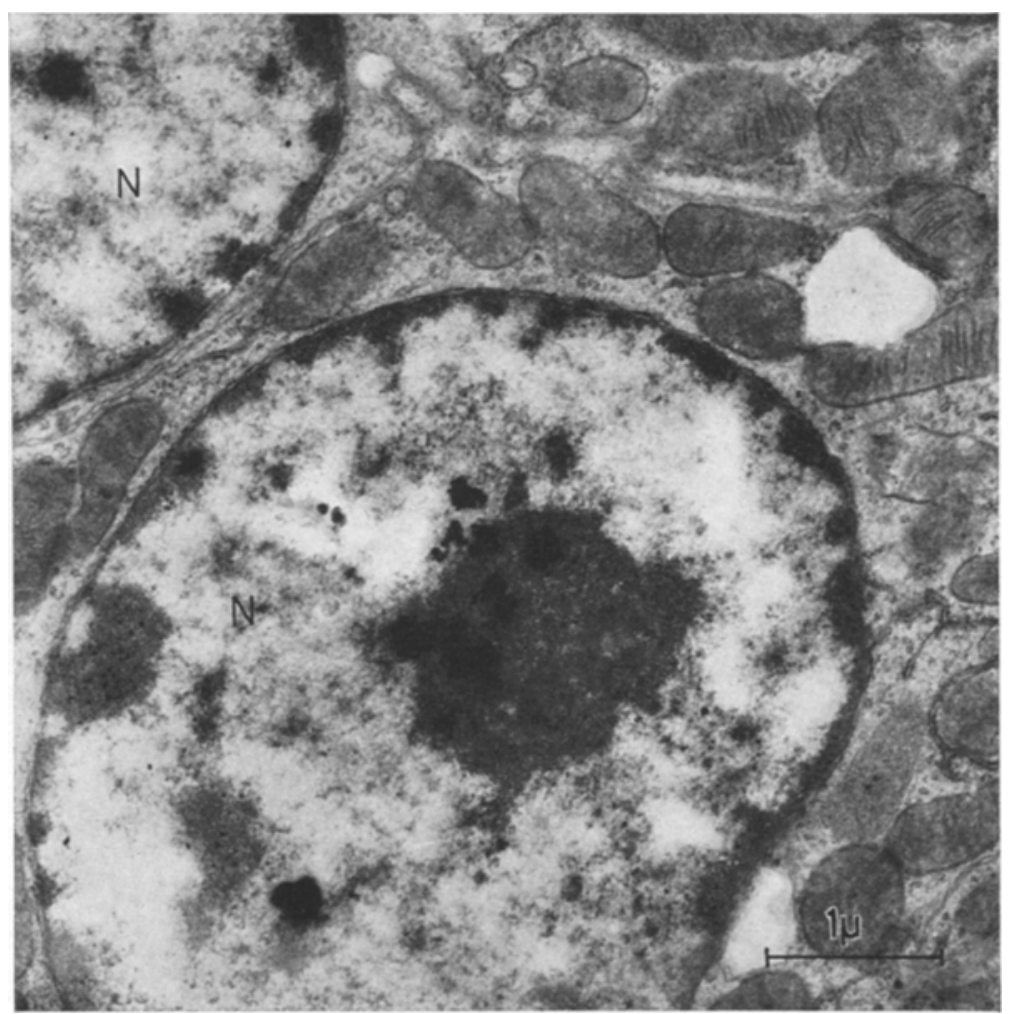

Fig. 19. Same animal as in Fig. 15. Radioactivity present in nucleus (N) of a cell of proximal convoluted tubule, both on chromatin and in nucleolus. $\times 18000$

\section{Discussion}

That FTTC-insulins prepared by us did not contain uncoupled insulin and were hormonally active preparations has been shown by the chemical, immunological and biological tests performed. This is in agreement with the data reported by ARQUILIA et al. (1966) but altered by the number of atoms of $\mathrm{I} /$ mole insulin (Izzo et al., 1964b) Since the localization of the fluorescent, biologically and immunologically active hormone and that of the ${ }^{125}$ I-insulin coincided, however, further tests of the biological properties of the latter preparation were not performed 
A number of authors (ELGEE and WILLTAMS, 1954; NARAHARA, 1955; LAHE, 1959; LeE and WisemaN, 1959; StEIN and Gross, 1959) have investigated biochemi-

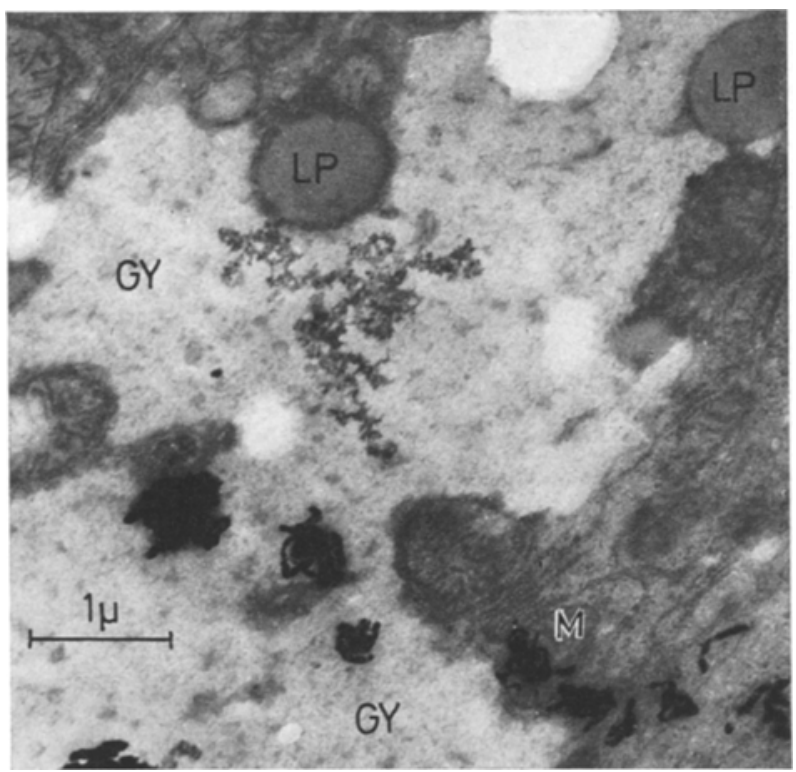

Fig. 20. Liver of a fully-fed mouse injected with $0.15 \mu \mathrm{O}$ 125I-insulin/g body weight and killed after $15 \mathrm{~min}$. $\mathrm{Ex}$ perimental procedure as above. Section exposed for 6 weeks. Radioactivity in glycogen area $(G Y)$ and in mitochondrion close to glycogen area (M). Lipid droplets are frequent in periportal spaces in these animals. Two are seen in this photograph (LP). $\times 15000$ protein in most tissues except in the liver, where degradation began $5 \mathrm{~min}$ after injection. With the routine histological processing adopted in the present experiments, involving the use of water-soluble fixatives and other solvents, it can be assumed that little if any degradation products can be left in the tissues. Moreover, the careful controls performed autoradiographically by WoRTHINTON et al. (1964) using enzymatically degraded ${ }^{125} \mathrm{I}$-monoiodotyrosine and $\mathrm{Na}^{125} \mathrm{I}$, were all negative. Hence, biochemical controls of the protein nature of the radioactivity found in the tissues of our animals were thought to be unnecessary.

1. Uptake of insulin by kidney: this tissue took up the greatest amount of radioactive insulin. The role of the kidney in the re-absorption of low molecular weight proteins from the glomerular filtrate has been well documented (for a review of this subject see MaUNSBaOH, $1966 \mathrm{~b}$ ) and has been shown by MaGGI (1966) using FITC-RNAse and FITC-albumin. This process occurs by pinocytic absorption and formation of protein droplets which are believed to reach the Golgi apparatus and to fuse with the primary lysosomes to form secondary lysosomes, where proteolysis takes

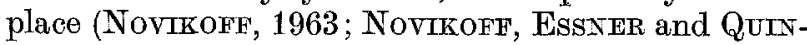
TANA, 1967). It was important to assess whether this was the mechanism whereby insulin was absorbed by the kidney cells, or whether a more specific type of absorption leading to the storage of the hormone for specific metabolic purposes was occurring. Evidence for a specific uptake of insulin, different from that of other types of proteins derives from the following facts:

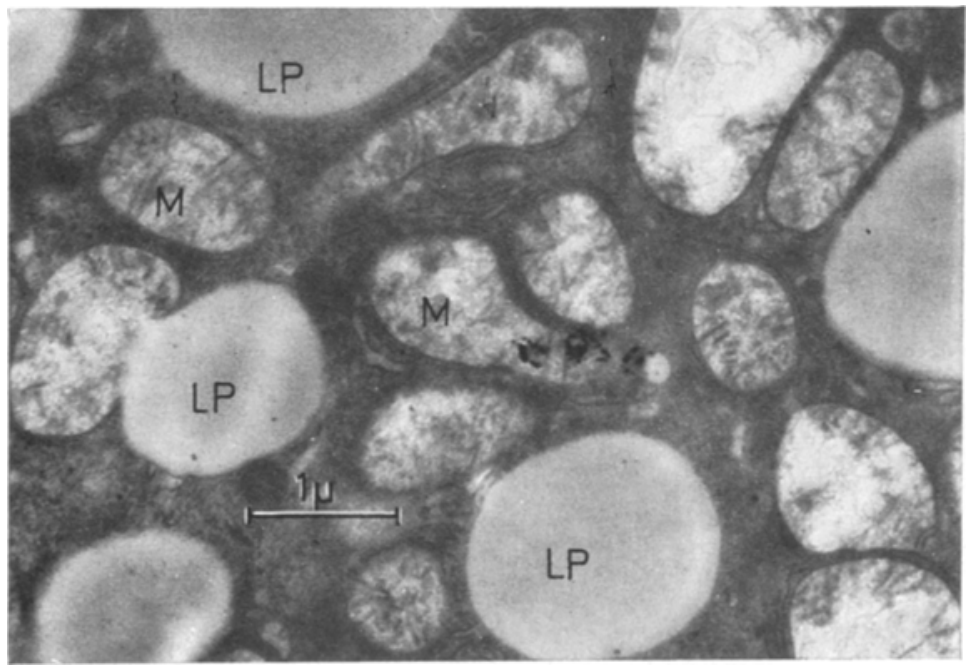

Fig. 21. Liver of animal starved for $18 \mathrm{~h}$, injected with $0.15 \mu \mathrm{C}$ 125T. insulin/g body weight and killed after $15 \mathrm{~min}$. Section exposed for 6 weeks. Radioactivity present in mitochondrion. The liver appears depleted of glycogen and a considerable number of large lipid droplets (LP) are present. $\times 15000$

cally the nature of the radioactivity present in animal tissues after injection of radioactive insulin. They found that at the time intervals used in the present experiments the radioactivity was in the form of a
Insulin is taken up in greater amounts by the kidney of fasted animals than by the kidney of fed animals. This difference is so striking that in the case of FITC-insulin no fluorescence due to the protein could 
be seen in the kidney of fed animals (MAGGI, 1966), and a much more sensitive technique, such as autoradiography, was needed to show that the kidney of fed animals also takes up the hormone, albeit to a limited extent. No such difference between fed and fasted animals was found when using FITC-RNAse or FITC-albumin (MAGGI, 1966).
1000 and $1400 \AA$ (Caro, 1962; Maunsbach, $1966 \mathrm{~b}$; RoG.ERS, 1967). The method adopted for the evaluation of the subcellular localization of the radioactivity in the tissues has shown that no radioactivity is likely to be present in the lysosomes or the Golgi apparatus at any time after the injection of ${ }^{\mathbf{1 2 5}} \mathrm{I}$-insulin; the radioactivity is found consistently in other subcellular struc-

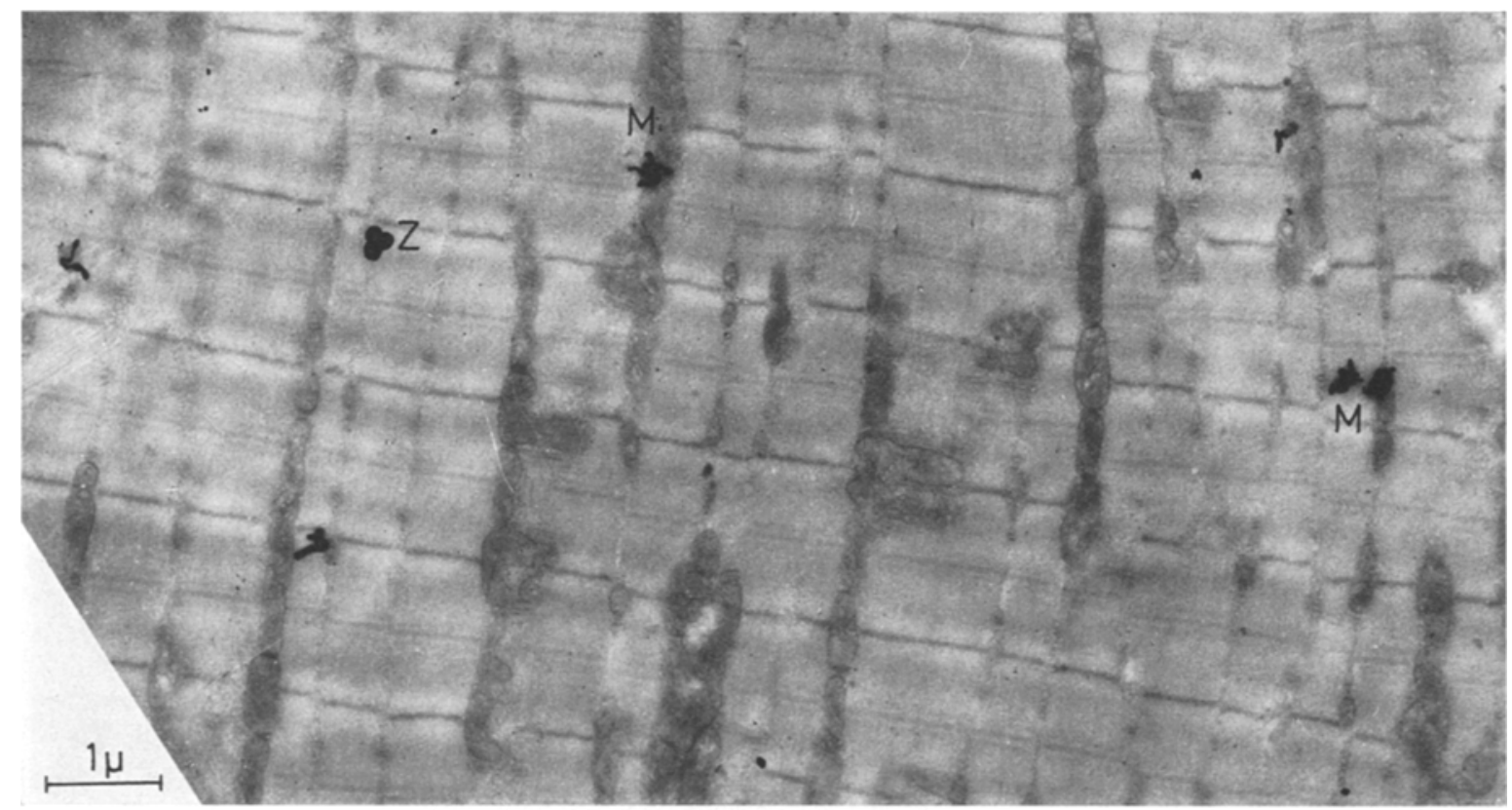

Fig. 22

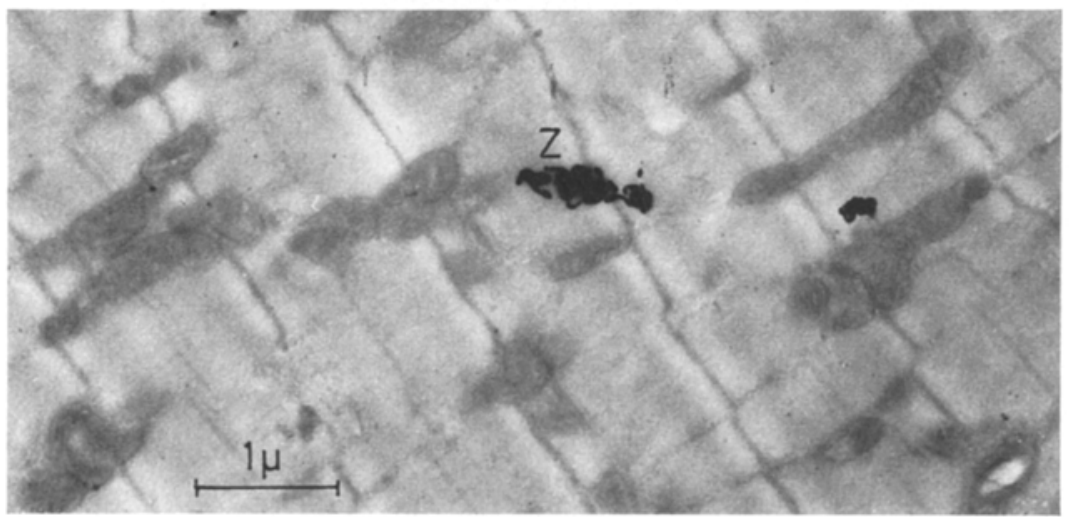

Fig. 23

FITC-insulin disappeared from the kidney after administration of glucose (MagGI, 1966). This would seem to indicate metabolic specificity.

Trypan blue is a dye specifically taken up by lysosomes (Btck, 1965). When starved animals are pretreated with Trypan blue to visualize their kidney lysosomes, a subsequent injection of FITC-insulin shows the hormone in sites distinct from those of Trypan blue absorption (Fig. 4). The resolution of the electron microscope autoradiography technique used in the present study has been calculated to be between tures such as nuclei and apical mitochondria, brush border and large and small apical vacuoles. The chance that the sources of radioactivity may lie outside the latter group of organelles appears to be very small. From the autoradiographs examined it appears that the chances of the radioactivity being in the lysosomes and consistently producing silver grains above other subcellular organelles are very remote. This makes it unlikely that insulin is broken down by lysosomes, at least during the time intervals investigated which are the times during which the hormone remains chemi- 
cally intact and acts on glucose metabolism. It indicates also that the process of absorption is specific and that as a result, the hormone may be kept in the cells as an intact molecule while affecting several metabolic pathways.

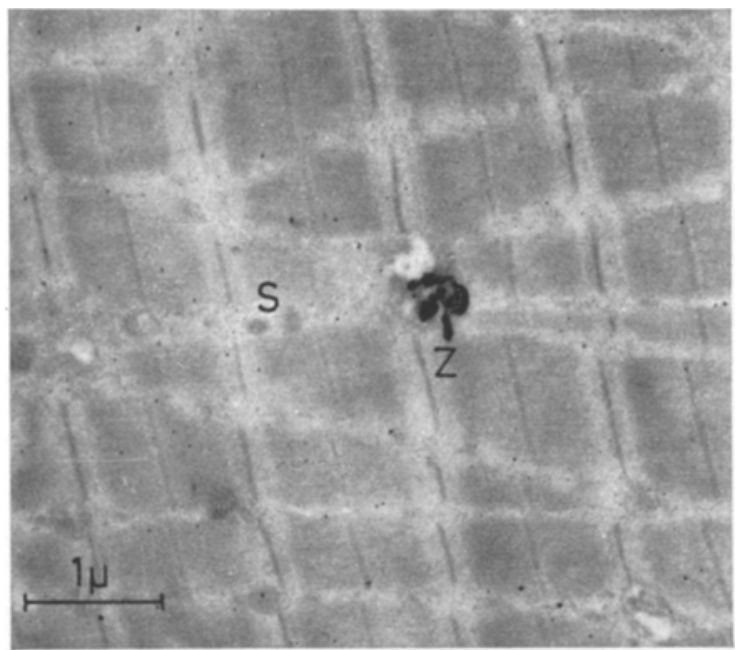

Figs. 22-23. Thigh muscle from fully-fed animals, Fig. 24 from animal starved for $18 \mathrm{~h}$. All animals were given $0.3 \mu$ ${ }^{125} \mathrm{I}$-insulin/g body weight and were killed after $5 \mathrm{~min}$. Tissue was fixed in $2.5 \%$ glutaraldehyde in $0.1 \mathrm{M}$ cacodylate buffer at $\mathrm{pH} 7.4$ for $1 \mathrm{~h}$, dehydrated in ethanol and embedded in Araldite. Autoradiograph 3 to 6 weeks exposure: unstained sections. Radioactivity can be seen in the mitochondria (M), close to the $\mathrm{Z}$ lines, and in the sarcoplasm (Fig. 24). Fig. $22 \times 12000$; Fig. $23 \times 15000$; Fig. $24 \times 13500$

A characteristic sub-cellular localization was found also in the liver within the first five minutes after the injection, and in striated muscle. No radioactivity was found in liver lysosomes; the radioactivity was found mainly in mitochondria, glycogen areas, lipid droplets, in the liver, and in interstitial tissue, and intercalated mitochondria in the striated musele. No evidence of pinocytic absorption in either of these two tissues was found. It is also interesting that in these latter two tissues the amount of hormone taken up, whether this is tested with extremely high (FITC-insulin) or with very low (125I-insulin) doses, is smaller (liver) or very much smaller (muscle) than in the kidney. This has been pointed out repeatedly in the literature (NARAHARO, 1958; WORTHINGTON et al., 1964; LeE and Wisemar, 1959; Gross and STEIN, 1959), but no attempt has been made to elucidate the precise function of the kidney with respect to storage, hormonal function and metabolism of insulin.

The role of insulin in controlling metabolic pathways in voluntary muscle, adipose tissue, liver and heart has been reviewed by RANDLE et al. (1966). Although the kidney is not mentioned by these authors as a possible specific target organ for the hormone, it will be considered together with the other tissues mentioned for the purpose of discussion.

The principal action of insulin has been considered to be on the permeability of the cell membrane. Data supporting this suggestion have come mainly from studies on isolated rat diaphragm (see RANDLE et al., 1966). The data presented in this paper would suggest that this control occurs at different sites for the different types of cells examined in the present study, since radioactive insulin was found on the microvilli of the brush border and on the intercellular membranes of the cells of the proximal convoluted tubules, but never on cell membranes of hepatocytes, and the hormone was found both intra- and extra-cellularly in the muscle. If insulin acts on the permeability of the cell membranes in these three types of cells, it would appear that the sites at which this control occurs must be different in each tissue. It is possible also that the subcellular localization of the hormone depends on the compound to be transported across the membrane, and also on the direction taken by each compound whether from within to without the cell or vice versa. In the voluntary muscle insulin controls the passage of glucose and amino acids from extra- to intra-cellular spaces (RANDLE et al., 1966). In the liver it enhances the passage of amino acids from extra- to intra-cellular spaces (RANDLE et al., 1966) as well as activating ribosomes, thus controlling protein synthesis in at least two ways. The glucose output is restrained on the other hand (RANDLE et al., 1966), although this has been denied by Gambassi, Maggi and Matarazzo (1953), who found an increased glycogenolysis after intraportal administration of insulin to rabbits. Nothing is known about insulin action on membrane permeability to glucose and amino acids in the kidney and on its possible control of protein synthesis in this tissue. It is tempting to suggest that insulin may control the permeability of the mitochondrial as well as of the cell membrane, and that it may regulate in this manner the transport and phosphorylation of glucose, which is known to be under respiratory control. It is also very tempting to consider the nuclear localization of the hormone as indicating the site of control of protein synthesis. The release of glucose from liver glycogen could be controlled by the hormone found in the glycogen areas in fed animals, whereas in fasted animals the hormone would be expected to increase the mobilization of liver fatty acids and triglycerides to the adipose tissue where it enhances lipogenesis and fatty acid esterification and inhibits lipolysis (RANDLE et al., 1966). Its presence within the fat droplets of both kidney and liver may control this process.

Our data also show that insulin is taken up, albeit in a small amount, by all the tissues investigated. This is not surprising, since the hormone appears to affect many metabolic pathways. Although no investigation with high resolution autoradiography was performed on tissues other than kidney, liver and voluntary muscle, this technique may ultimately reveal different sub-cellular localizations and perhaps different types of control mechanism from those described in these three tissues in the present paper. 
Acknowledgements. Our thanks are due to Dr. P.B. GAfAN for allowing us to make use of the A.E.I. E.M.6B electron microscope, to Dr. G. Grrand and Miss Gillutan D. Bervant for the preparation of ${ }^{125} \mathrm{I}$-insulin, to Dr. B. M. A. DAvtes for having performed the insulin immuno assays, to Dr. W.W. Bromer and Dr. O. BeHrens of Lilly Research Laboratories, to Dr. B.A.L. HuRN of Burroughs and Wellcome, and to Dr. ScHLTCHTKRULL of Novo Research Laboratories for the large amounts of crystalline insulins supplied. We gratefully acknowledge the technical assistance of Miss Mavra F. ODdx and Mr. M.E. BRoWN and the help of Mr. G. D. LEACH in processing the photographs.

\section{References}

ArquTrta, E.R., H. Ooms, and J.FrnN: Genetic differences of combining sites of insulin antibodies and im portance of C-terminal portion of the A-chain to biological and immunological activity of insulin. Diabeto logia 2, 1-13 (1966).

BECK, F.: The distribution of acid phosphatase in the chick blastoderm. Exp. Cell Res. 37,504-508 (1965).

Bromer, W.W., S. KNapp-SemenhaN, A.W. Berns, and E.R. ARquLLA: Preparation and properties of fluorescein thiocarbamyl insulins. Biochemistry 6, 2378-2388 (1967).

BUDD, G.C., and S.R. PExC: The membrane method of electron microscope autoradiography. Stain Technol. $39,295-302$ (1964).

Caro, L.G.: High resolution autoradiography. II. The problem of resolution. J. Cell Biol. 15, 189-199 (1962).

ELGEE, N.J., and R.H. Wircuams: Degradation of insulin- ${ }^{131}$ by liver and kidney in vivo. Proc. Soc. Exp. Biol. 87, 352-355 (1954).

Gambasst, G., V. Maggr, and C. Matarazzo: Sur le problème de l'inactivation hépatique de l'insuline in vivo. Acta med, scand. 153, 201-209 (1956).

GraUERT, A.M.: In Techniques for electron microscopy, 2nd edition. Editor: KAX,D.H., p. 166. Oxford: Blackwell Seient. Publ. 1965.

GrafaM, R.C., and M.J. Kannovsky: The early stages of absorption of injected horse-radish peroxidase in the proximal consoluted tubules of mouse kidney: ultrastructural cytochemistry by a new technique. J. Histochem. Cytochem. 14, 291-302 (1966).

Grexerwood, F.C., W.M. HUNTer, and J.S. GLover: The preparation of 131I-labelled human growth hormone of high specific activity. Biochem. J. 89, 114-123 (1963).

HALES, C.N., and P.J. RANDIE: Immunoassay of insulin with insulin-antibody precipitate. Biochem. J. 88, $137-146(1963)$.

Tzzo, J.I., W.F. Bare, M.J. Tzzo, and A. Roncone: High specific activity labelling of insulin with ${ }^{131} \mathrm{I}$. J. biol. Chem. 239, 3743-3748 (1964).

- A. Ronoone, M.J. Izzo, and W.F. BaLe: Relationship between degree of iodination of insulin and its biological electrophoretic and immunochemical properties. J. biol. Chem. 239, 3749-3754 (1964).

Kayas, J., A.B. MaUnsbach, and S. Uluberg: Electron microscopic autoradiography of radioiodine in the thyroid using the extranuclear electrons of $I^{125}$. J. ultrastruct. Res. 7, 339-345 (1962).
LEE, N. D. : The specificity of the interaction of insulin-I131 with tissue. Fndocrinology 65, 347-356 (1959).

-, and R. Wiskman, Jr.: The significance of the binding of insulin- $\mathrm{I}^{131}$ to cytostructural elements of rat liver. Endocrinology 65, 442-450 (1959).

LOWRY, O.H., N.J. ROSEBRoUGH, A.I. FARR, and R.J. RANDALL: Protein measurement with the Folin phenol reagent. J. biol. Chem. 193, 265-275 (1951).

MAger, V.: The localization of fluorescent insulin in mouse tissues. Exp. Cell Res. 44, 672-676 (1966).

-, and M.F. ODDX: Effect of short-term starvation on the cells of the proximal convoluted tubule of the mouse: a cytological and cytochemical study. The Histochemical Journal 1, 78-92 (1968).

MAUNsBaCH, A. B. : Absorption of $I^{125}$-labelled homologous albumin by rat kidney proximal convoluted tubule cells. A study of microperfused single proximal tubules by electron microscopic autoradiography and histo. chemistry. J. ultrastruct. Res. 15, 197-241 (1966a).

- Absorption of ferritin by rat kidney proximal tubule cells. J. ultrastruet. Res. 16, 1-12 (1966 b).

Messier, B., and C.P. LeBLond: Preparation of coated radioautographs by dipping sections in fluid emulsion. Proc. Soc. exp. Biol. 96, 7-10 (1957).

Naramara, H.T., N.B. EveretT, B.S. Simmoxs, and R.H. Winlrams: Metabolism of insulin-I ${ }^{131}$ and glucagon- $\mathrm{I}^{131}$ in the kidney of the rat. Amer. J. Physiol. 192, 227-231 (1958).

Novikorf, A.B.: Lysosomes in the physiology and pathology of cells; contribution of staining methods. In Ciba Found. Symp. on Lysosomes. London: J. \& A. Churchill Ltd. 1963.

- E. Essner, and N. QuintanA: Golgi apparatus and lysosomes. Fed. Proc. 23, 1010-1022 (1964).

Pexc, S.R.: Autoradiograph technique. Nature 160, $749-750(1947)$.

Randle, P.J., P.B. Garland, C.N. Hales, E.A. Newshotme, R.M. Denton, and C.I. Pocson: Interactions of metabolism and the physiological role of insulin. Recent Progr. Hormone Res. 22, $1-44$ (1966).

Rogers, A.W., Techniques of autoradiography. London and New York: Elsevier publ. Comp. Amsterdam 1967.

SchaLCH, D.S.: Use of $\mathrm{I}^{125}$-labelling in radioimmunoassay. Proc. Soc. exp. Biol. 121, 1279-1280 (1966).

SterN, O., and J. Gross: Localization and metabolism of $I^{131}$-insulin in the muscle and some other tissues of the rat. Endocrinology 65, 707-716 (1959).

Stravs, W., Comparative observations on lysosomes and phagosomes in kidney and liver of rats after administration of horse-radish peroxidase. CIBA Found. Symp. on Lysosomes $151-175,1963$.

Tremze, F., G. F. Morturome, and N.R. Lomax: Preparam tion and properties of fluoreseent insulin derivatives. Biochem. biophys. Acta. 59, 336-346 (1962).

Worthington, L.A. Jr., D. Jones, and M.G. Buse: Autoradiographic study of insulin distribution in the rat with special reference to elastic tissue. Endocrinology 74,914-924 (1964).

Dr. Viviane MagGt

Imperial Cancer Research Fund Department of Cellular Pathology Lineoln's Inn Fields London, W.C. 2, England 